\section{DIGITAL COMMONS \\ @ UNIVERSITY OF SOUTH FLORIDA}

Journal of Practitioner Research

\title{
Practitioner Experiences in Teacher Education Partnerships: Examining Practice in an Accredited Professional Development School
}

Jennifer J. Roth

Colorado State University - Fort Collins, jroth@psdschools.org

Derek Decker

Colorado State University, derek.decker@colostate.edu

Donna D. Cooner

Colorado State University - Fort Collins, donna.cooner@colostate.edu

Follow this and additional works at: https://digitalcommons.usf.edu/jpr

Part of the Higher Education Commons, Higher Education and Teaching Commons, Other Teacher Education and Professional Development Commons, and the Secondary Education and Teaching Commons

\section{Recommended Citation}

Roth, Jennifer J.; Decker, Derek; and Cooner, Donna D. (2019) "Practitioner Experiences in Teacher Education Partnerships: Examining Practice in an Accredited Professional Development School," Journal of Practitioner Research: Vol. 4 : Iss. 2 , Article 3.

https://doi.org/10.5038/2379-9951.4.2.1059

Available at: https://digitalcommons.usf.edu/jpr/vol4/iss2/3

This Practitioner Research is brought to you for free and open access by the Open Access Journals at Digital Commons@ University of South Florida. It has been accepted for inclusion in Journal of Practitioner Research by an authorized editor of Digital Commons @ University of South Florida. For more information, please contact digitalcommons@usf.edu. 


\title{
Practitioner Experiences in Teacher Education Partnerships: Examining Practice in an Accredited Professional Development School Network
}

\begin{abstract}
:
In this qualitative study, practitioner researchers used focus group methodology to collect clinical partnership stakeholders' descriptions of their understanding of rich practitioner practice and the benefits of clinical partnerships as defined by CAEP Standard 2. These descriptions provided the data that was analyzed through a deductive and inductive coding process. It was found that stakeholders described clinical experiences as crucial to teacher candidates' development of knowledge, skills, and professional dispositions, and identified clinical experiences as the space where theory and practice intersect. Findings also showed that stakeholders identified collaboration, mutually beneficial, sustaining and generative, shared accountability, and positive impact as the key components in a clinical partnership.
\end{abstract}

In its report Preparing Teachers: Building Evidence for Sound Policy (2010), the National Research Council challenged educator preparation programs in universities across the nation to develop, implement, and improve practitioner partnerships and practices to facilitate field and clinical experiences instrumental in the development of effective educators. The report aimed to raise the performance of teacher candidates as practitioners in the nation's PK-12 schools, and to raise standards for the evidence the field relies on to supports its claims of quality. Practitioners include those actively involved in the profession of education-including practicing teachers in PK-12, professors from higher education educator preparation program. One important and critical change has resulted in the Research Council report identified content knowledge, clinical experience and teacher candidate quality as the three aspects of teacher preparation most likely to have the strongest effect on raising PK-12 student achievement (National Research Council, 2010). These three aspects, as well as quality assurance, continuous improvement, public accountability and transparency, formed the basis for new teacher preparation standards. The Council for the Accreditation of Educator Preparation (CAEP) standards represented a unified voice in accreditation, elevating the importance of clinical experiences by clearly defining practitioner partnerships and making them a requirement for accreditation.

\section{Current Study}

As illustrated in Table 1.1, CAEP's Standard 2: Practitioner Partnerships and Practice is broken down into three sub-sections: Partnerships for Practitioner 
Practice, Practitioner Educators, and Practitioner Experiences. Given the scope of Standard 2 and time constraints for data collection and analysis, the researchers chose to focus on Standard 2.1: Practitioner Partnerships and Standard 2.3: Practitioner Experiences.

Table 1.1

CAEP Standard 2: Practitioner Partnerships and Practice

\begin{tabular}{|c|c|c|}
\hline & Title & Description \\
\hline Standard 2.1 & $\begin{array}{l}\text { Partnerships for } \\
\text { Practitioner } \\
\text { Preparation }\end{array}$ & $\begin{array}{l}\text { Partners co-construct mutually beneficial } \\
\text { P-12 arrangements for practitioner } \\
\text { preparation and share responsibility for } \\
\text { candidate preparation. Partners establish } \\
\text { mutually agreed upon expectations for } \\
\text { candidate entry, preparation and exit; } \\
\text { ensure a linking of theory and practice; } \\
\text { maintain coherence across practitioner and } \\
\text { academic preparation; share accountability } \\
\text { of candidate outcomes. }\end{array}$ \\
\hline Standard 2.2 & $\begin{array}{l}\text { Practitioner } \\
\text { Educators }\end{array}$ & $\begin{array}{l}\text { Partners co-select, prepare, and evaluate } \\
\text { high-quality practitioner educators who } \\
\text { demonstrate positive impact on candidates' } \\
\text { development and P-12 student learning and } \\
\text { development. Partners use multiple } \\
\text { indicators to establish/refine criteria for } \\
\text { selection, professional development, } \\
\text { evaluation, improvement, and retention of } \\
\text { practitioner educators. }\end{array}$ \\
\hline Standard 2.3 & $\begin{array}{l}\text { Practitioner } \\
\text { Experiences }\end{array}$ & $\begin{array}{l}\text { Provider and partners design practitioner } \\
\text { experiences of sufficient depth, breadth, } \\
\text { diversity, coherence, and duration to ensure } \\
\text { that candidates demonstrate effectiveness } \\
\text { and positive impact on student learning. } \\
\text { Experiences have multiple assessments to } \\
\text { demonstrate candidates' development of } \\
\text { knowledge, skills, and professional } \\
\text { dispositions associated with a positive } \\
\text { impact on learning and development of P- } \\
12 \text { students. }\end{array}$ \\
\hline
\end{tabular}

Note: Adapted from CAEP Accreditation Standards and Evidence: Aspirations for Educator Preparation (CAEP, 2013). 
The purpose of this study was to describe the practitioner partnerships and practitioner experiences embedded in Colorado State University's (CSU) Educator Preparation Program (EPP) as perceived and understood by the three key stakeholders, CSU Center of Educator Preparation (CEP) faculty, school-based educators and teacher candidates through the lens of the CAEP accreditation standards for Practitioner Partnerships and Practice (CAEP, 2013). This research was approved by the Institutional Review Board of Colorado State University.

\section{Description of Colorado State University's PDS}

At CSU, the CEP uses a PDS model as a framework for the undergraduate, post-bachelor, and graduate teacher licensure programs. Crafted through over two decades of on-going research and collaboration, the effective elements of a PDS, including the preparation of new teachers, development of faculty, improvement of practice and focus on PK-12 student achievement are evident in the structure of CSU's program ("Professional development schools and partnerships," 2015). The CSU CEP maintains strong partnerships with thirty elementary, middle, and high schools in three area public school districts by implementing a PDS model with upwards of 600 teacher candidates. Engaging in practitioner experiences in public schools each semester, these teacher candidates are supported by approximately 100 local school-based educators who serve in variety of partnership roles as mentors, cooperating teachers and site instructors, and approximately 25 university-based educators who are involved in the practitioner instruction of teacher candidates.

Teacher licensure is structured into four semester-long phases. Each phase includes one or two courses that embed practitioner experience ranging from eight hours (in Phase 1) to a fifteen-week, full-time student teaching practicum (in Phase 4) on-site at a middle or high school in one of the three surrounding districts. In total, teacher candidates complete the teacher preparation program with 800 hours of practitioner experience ("Model of the teacher licensure program," 2012). Table 1.2 illustrates the coursework and field work associated with the four phases of the PDS Educator Licensure Program at CSU. 
Table 1.2

Courses in Phases of PDS Educator Licensure Program at Colorado State University

\begin{tabular}{|c|c|c|c|}
\hline Phase I & Phase II & Phase III & Phase IV \\
\hline $\begin{array}{l}\text { "Schooling in the } \\
\text { United State" } \\
\text { (field experience } \\
\text { in PK-12 school) } \\
\text { "Literacy and the } \\
\text { Learner" (field } \\
\text { experience in PK- } \\
12 \text { school) }\end{array}$ & $\begin{array}{l}\text { "Instruction I: } \\
\text { Individualization, } \\
\text { Management" } \\
\text { (taught on-site at } \\
\text { public middle } \\
\text { school; includes } \\
\text { classroom field } \\
\text { experience) } \\
\text { "Practicum: } \\
\text { Instruction I" } \\
\text { (field experiences } \\
\text { aligned with } \\
\text { Instruction I) }\end{array}$ & $\begin{array}{l}\text { "Instruction II: } \\
\text { Standards, } \\
\text { Assessment" } \\
\text { (taught on-site at } \\
\text { public high } \\
\text { school; includes } \\
\text { classroom field } \\
\text { experience) } \\
\text { "Practicum: } \\
\text { Instruction II" } \\
\text { (field experiences } \\
\text { aligned with } \\
\text { Instruction II) }\end{array}$ & $\begin{array}{l}\text { "Student } \\
\text { Teaching" (15- } \\
16 \text { weeks of full- } \\
\text { time field } \\
\text { experience on- } \\
\text { site in school } \\
\text { setting) }\end{array}$ \\
\hline
\end{tabular}

Note: Adapted from "Model of the teacher licensure program" (2012).

CSU was awarded national accreditation from TEAC in 2009. In July 2013, TEAC consolidated with NCATE to form CAEP, the sole national accrediting body in the United States. In January 2015, CSU underwent the accreditation process through CAEP; however, TEAC standards were still applied. Looking forward, CSU will need to meet the CAEP standards that were fully implemented in 2016 for the next accreditation visit. For this reason, it is imperative to understand how CSU's current practitioner partnerships and practices align with the CAEP standards delineated in Table 1.1. This paper briefly traces the history of the development of practitioner practices, specifically the Professional Development School (PDS) model, examines the role of national accreditation in the development of practitioner practices, explicates the practitioner experiences at Colorado State University's (CSU) PDS educator preparation program as understood by the members of the practitioner partnership, and analyzes the alignment of the current Council for the Accreditation of Educator Preparation (CAEP) standard for practitioner partnerships and practice with current model in place at CSU. The findings presented in this study will add to the body of research that supports the critical importance of practitioner experiences to the development of quality beginning teachers. 


\section{Review of Literature}

\section{Improving Teacher Effectiveness Through Quality Educator Preparation}

In 1983, A Nation at Risk: The Imperative for Education Reform criticized educator preparation programs for establishing low standards for potential candidates and maintaining a curriculum that focused too heavily on methods classes at the expense of coursework in content areas (National Commission on Excellence in Education, p. 74). Since that time, there has been a strident demand to improve teacher quality. Williams (2000) emphasized "the single most important factor related to student learning is teacher quality. This has particular relevance for our urban and rural areas, where schools . . . are often asked to do more to compensate for the paucity of outside-of-school educational support systems" (p. 57). Cochran-Smith (2006) reported "teacher quality is one of the most, if not the most, significant factor in students' achievement and educational improvement" (p. 106).

To address teacher quality, national reform has focused on how best to improve educator preparation programs. The criticism of educator preparation programs has ranged from "weak accreditation policies and practices, and historic disinterest in teacher preparation on the part of major research universities" (Murray,1986) to disconnected faculty, lack of training to work with diverse students, low admission standards for students into school of education program, lack of quality control, and lack of agreement about educator preparation curriculum (Levine, 2006). Traditional student teaching, typically a 16-week practicum working in an actual classroom in the final semester of coursework, has been found to provide inadequate time in the classroom and offer few opportunities to translate theory to practice, resulting in graduates generally feeling ill-prepared to face the challenges of being in their own classroom (Sandholtz \& Wasserman, 2001). In response to these deficiencies, many educator preparation programs (EPPs) have been redesigned to incorporate practitioner practice through partnerships with local PK-12 school districts.

\section{Educator Preparation and Practitioner Partnerships and Practice}

Modeled after the practitioner experiences of medical students in teaching hospitals, clinical practice in educator preparation involves carefully scaffolded learning to provide teacher candidates with concrete ways to connect theory to practice. Simulated classroom experiences (e.g., videoed lessons for discussion and role-play) are embedded in university coursework. Similar to medical rotations, instructional rounds provide the opportunity for teacher candidates to engage in 
supervised observations in actual classrooms followed by group analysis and discussion between the student observers and the teacher education faculty (Zimpher \& Howey, 2013). The implementation of practitioner partnerships between universities and PK-12 public schools has been widely recommended as a way to create meaningful practice opportunities into teacher preparation programs (Carnegie Forum on Education and the Economy, 1986; Darling-Hammond, 2006; Goodlad, 1990; Goodlad, 1994; Murray, 1986). Practitioner experiences permit the blending of content and pedagogy in reiterative and reflective processes through which teacher candidates can partner with master teachers to engage in hands-on training in both the university and public school classroom.

One model of practitioner practice that has gained significant traction is the PDS, which is:

specially structured school in which Educator Preparation Provider (EPP) and $\mathrm{P}[\mathrm{K}]-12$ school practitioner educators collaborate to (1) provide practicum, field experience, practitioner practice, and internship experiences; (2) support and the professional development of the EPP and $\mathrm{P}[\mathrm{K}]-12$ school practitioner educators; (3) support and enable inquiry directed at the improvement of practice; and (4) support and enhance P[K]12 student achievement ("Professional development school," 2015).

With more than 600 PDSs implemented during the 1990s (Abdal-Haqq, 1998), these "practitioner field sites [allow] school and university partners [to] focus together on improving teacher education and the professional development of practicing teachers as well as increasing student achievement and conducting research" (Castle, Fox, \& Souder, 2006, p. 65). The collaborative practices of a PDS create opportunities for teacher candidates, educators, and students to participate in simultaneous renewal, critical theory-to-practice educational experiences that are mutually beneficial to all parties (Goodlad, 1990; Goodlad, 1994).

\section{Research on the Effectiveness of Practitioner Practices to Improve Teacher Preparation}

Studies comparing teacher candidates trained in programs that emphasize practitioner practices such as PDSs to EPPs with the traditional semester-long student teaching experience have demonstrated a variety of advantages and benefits: increased efficacy and confidence, more positive attitudes toward the teaching profession, better preparation for the realities of teaching, deeper knowledge of content, pedagogy, and assessment, lower attrition rates, and better 
developed team and leadership skills (Sandholtz \& Wasserman, 2001). Castle, Fox and Fuhrman (2009) found that those trained in a PDS program versus a traditional program had more positive results regarding emerging beliefs, attitudes, dispositions and skills necessary to be effective educators. In particular, the PDS teacher preparation produced "beginning teachers who are more competent in some aspects of instruction, management, and assessment, and are more integrated and student-centered in their thinking about planning assessment, instruction, management and reflection" (Castle, et al., 2009, p. 78). Boyd, Grossman, Lankford, Loeb, and Wyckoff (2009) suggested that educator preparation centered on the practice of teaching, for example, a strongly supervised student teaching experience or a practitioner capstone project, produced more effective first-year teachers than traditionally prepared teachers as measured by their student achievement gains. In a study comparing student achievement in two elementary schools, one with an embedded PDS and one without, Castle, Arends and Rockwood (2008) found that more students in the school with a PDS program moved to mastery level and out of intervention level on state standardized testing than students in the non-PDS school.

\section{Practitioner Partnerships and National Accreditation}

National teacher organizations, alliances, and accrediting bodies have supported the calls to reform and invigorate EPPs by clearly defining practitioner partnerships and by recommending more uniform and consistent implementation of practitioner partnerships and practices. In its report "Reforming Teacher Education: The Critical Practitioner Component" (2010), the American Association of Colleges for Teacher Education (AACTE) asserted that "the skilled application of theory to benefit a student is developed through learning situated in practice, interacting with real children of various cultural backgrounds and developmental levels, under the guidance of experienced mentors" (p. 6). The National Council for the Accreditation of Teacher Education (NCATE) produced a report, Transforming Teacher Education through Practitioner Practice: A National Strategy to Prepare Effective Teachers (2010), calling for the overhaul of the teacher education programs in the United States by interweaving academic, pedagogical, and professional content into the practitioner practice experiences of teacher candidates.

NCATE and the Teacher Education Accreditation Council (TEAC) consolidated into CAEP in 2013 and became the sole accrediting mechanism for EPPs across the United States. For an EPP to be accredited through CAEP, evidence must be presented for five clearly articulated standards: (a) Content and Pedagogical Knowledge, (b) Practitioner Partnerships and Practice, (c) Candidate 
Quality, Recruitment, and Selectivity, (d) Program Impact, and (e) Provider Quality Assurance and Continuous Improvement (Council for the Accreditation of Educator Preparation [CAEP], 2013). The CAEP Standard 2: Practitioner Partnerships and Practice is divided into three sub-standards: Partnerships for Practitioner Preparation, Practitioner Educators, and Practitioner Experiences (CAEP, 2013).

CAEP's expectation of the inclusion of practitioner partnerships and practices in a university EPP to receive national accreditation renders the development of this component of teacher preparation programs an urgent priority for universities and colleges.

\section{Methods}

The design of this research is a basic interview study. Participant reflections included system of CSU's PDS and the interaction of its key stakeholders, the university-based educators, the school-based educators in the partnership schools and the teacher candidates. Additionally, the researchers had access to program participants because of their respective roles as a CSU instructor and high school partner site administrator.

\section{Research Questions}

The following research questions guided the analysis of the interview data:

1. How do University Based Teacher Educators (UBTEs), School Based Teacher Educators (SBTEs), and teacher candidates describe the practitioner experiences embedded in CSU's PDS model of educator preparation?

2. How do the descriptions of CSU's practitioner experiences by UBTEs, SBTEs, and teacher candidates align with Practitioner Experiences as defined by CAEP's Standard 2.3?

\section{Participants}

Participants were recruited from the key stakeholder groups in the CSU PDS partnership: CSU CEP university-based teacher educators (UBTEs), school-based teacher educators (SBTEs) at one local high school who had hosted PDS practicum students and/or student teachers, and teacher candidates in their final 16-week practitioner experience. The researchers decided on the focus group method for 
data collection because of its inherent advantages that include efficiency to obtain data from multiple participants; the socially oriented environment that increases a sense of belonging and safety to disclose information; and, the spontaneous nature of group conversation that allows participants to build upon responses of others (Onwuegbuzie, Dickinson, Leech \& Zoran, 2009). The focus groups were purposively selected to yield data that would illuminate the key stakeholders' understandings of practitioner practices at CSU. Focus groups were self-contained (Morgan, 1997) and served as the source of qualitative data used for analysis. Three separate one-hour sessions were scheduled for each focus group. The researchers conducted the focus group for CSU CEP faculty on campus and the focus groups for the SBTEs and teacher candidates in a conference room at a local high school. All three focus groups were conducted at the end of November, 2014 allowing for the teacher candidates to reflect upon and speak about their entire practitioner experiences from Phase I through nearly the end of Phase IV. Practitioner researchers co-facilitated the focus groups in which a total of $12 \mathrm{CSU}$ faculty, eight school-based educators, and eight teacher candidates participated.

Below are the focus group questions that were asked.

1. Within the context of CSU, what is your understanding of a clinical experience?

2. What are the benefits of a clinical experience?

3. What are the barriers that keep you from realizing those benefits?

\section{Procedures}

Prior to the sessions, all participants signed an informed consent form. The researchers co-facilitated each focus group. The dialogue during the focus group interviews was audio recorded with Microsoft Lifecam software. The researchers provided participants with a copy of the interview guide prior to beginning the focus group. An overview of the CAEP Standard 2: Practitioner Partnerships and Practice 2.1: Partnerships for Practitioner Preparation and three open-ended questions were printed on one side of the focus group guide. The CAEP Practitioner Partnerships and Practice 2.3: Practitioner Experiences and three open-ended questions were on the other side of the guide. Participants were asked to read the overviews and ask clarifying questions of the researchers. The participants were prompted to respond to the three questions focusing specifically on practitioner partnerships for 30 minutes and then respond to the same questions focusing on practitioner experiences for the next 30 minutes. The audio recordings were submitted to a transcription service that provided verbatim transcription of 20-25 pages per focus group. 


\section{Data Analysis}

Practitioner researchers individually reviewed the transcripts from each focus group to determine which portions of the transcription corresponded to practitioner partnerships and practitioner experiences and to identify broad themes that emerged from the transcripts. The researchers then met to compare, discuss, and refine the individually identified themes. Although overlap existed between the components of practitioner partnerships and practitioner experiences, the researchers strove to separate the two concepts by determining whether the data supported practitioner partnerships or practitioner experiences to better analyze the data through the lens of CAEP's Standard 2.1 and 2.3. It should be noted that at this point, the authors of this article analyzed data associated with practitioner experiences and it is this analysis that is presented in this paper.

Following the initial reading and subsequent discussion about the transcripts, the researchers entered the interview transcriptions for Practitioner Experiences into the QSR NVivo data management program and a comprehensive data-coding process was undertaken. A hybrid method of deductive and inductive content analysis was employed. An unconstrained categorization matrix (Elo \& Kyngäs, 2008) of a priori codes that reflected the components of a practitioner experience as defined by CAEP Standard 2.3 was created in advance of any analysis of data. These codes were used to create NVivo nodes. The a priori codes were the following: performance-based assessment, sufficient depth, breadth and duration of experience, diversity of experience, positive impact on PK-12 students, development of skills and knowledge, and development of professional dispositions. Following the principles of inductive content analysis (Elo \& Kyngäs, 2008), emerging themes that clarified or elaborated upon the a priori codes were added as child nodes. For example, within the code development of knowledge and skills, six more specific themes emerged and were coded: classroom and school routines, classroom management, differentiation, district expectations, lesson planning and enacting lessons, and developing teacher identity. Open coding was used for emerging themes that did not fit the pre-existing categorization matrix; new nodes were added in NVivo. For example, a node labeled, praxis, with three associated child nodes, hands-on practice, realistic expectations, and reflective practice, was incorporated as the analysis of the focus group data progressed.

Although presented as a linear, step-by-step procedure, the research analysis was an iterative and reflexive process. After the transcripts for the three focus groups were coded, the researchers printed, read through all the data for each node, and wrote notes in the margins. In some instances, new categories and subcategories were generated and the data re-organized to reflect a deeper 
understanding on the part of the researchers.

\section{Findings}

Upon completion of the coding process, practitioner researchers identified seven main themes, six of which were a priori themes that aligned with essential components of the CAEP Standard 2.3: assessments, depth, breadth, and duration, diversity, impact on P-12 students, professional dispositions, and knowledge and skills. One emerging theme identified through the coding process was praxis. Of the seven themes, four main themes (depth, breadth, and duration, professional dispositions, knowledge and skills, and praxis) were referenced by the three stakeholder groups and are explored more in this section.

Table 1.3

A Priori and Emerging Themes with Sources and Number of References

\begin{tabular}{|c|c|c|c|c|}
\hline Theme & Definition $^{a}$ & $\begin{array}{l}\text { Sources } \\
(\mathrm{F}, \quad \mathrm{CT}, \\
\mathrm{ST})^{\mathrm{b}}\end{array}$ & $\begin{array}{l}\text { No. of } \\
\text { times } \\
\text { reference } \\
\text { d }\end{array}$ & $\begin{array}{l}\text { a priori } \\
\text { vs. } \\
\text { emerging }\end{array}$ \\
\hline 1. Assessments & $\begin{array}{l}\text { Multiple, performance- } \\
\text { based assessments at key } \\
\text { points within program }\end{array}$ & CT & 2 & a priori \\
\hline $\begin{array}{l}\text { 2. Depth, breadth, } \\
\text { and duration }\end{array}$ & $\begin{array}{l}\text { Sufficient depth, breadth } \\
\text { and duration to ensure } \\
\text { candidate's developing } \\
\text { effectiveness }\end{array}$ & $\mathrm{F}, \mathrm{CT}, \mathrm{ST}$ & 11 & a priori \\
\hline 3. Diversity & $\begin{array}{l}\text { Sufficient diversity to } \\
\text { ensure candidate's } \\
\text { developing effectiveness }\end{array}$ & $\mathrm{F}, \mathrm{ST}$ & 3 & a priori \\
\hline $\begin{array}{l}\text { 4. Impact on PK- } \\
12 \\
\text { students }\end{array}$ & $\begin{array}{l}\text { Positive impact on learning } \\
\text { of PK-12 students }\end{array}$ & $\mathrm{CT}, \mathrm{ST}$ & 3 & a priori \\
\hline $\begin{array}{l}\text { 5. Professional } \\
\text { dispositions }\end{array}$ & $\begin{array}{l}\text { Demonstration of } \\
\text { candidate's development } \\
\text { of professional } \\
\text { dispositions }\end{array}$ & $\mathrm{F}, \mathrm{CT}, \mathrm{ST}$ & 23 & a priori \\
\hline $\begin{array}{l}\text { a. Care and } \\
\text { compassion }\end{array}$ & & ST & 7 & emerging \\
\hline b. Collaboration & & $\mathrm{F}, \mathrm{CT}$ & 4 & emerging \\
\hline
\end{tabular}




\begin{tabular}{|c|c|c|c|c|}
\hline \multirow{2}{*}{$\begin{array}{l}\text { c. Value of } \\
\text { feedback } \\
\text { d. Learning from } \\
\text { mistakes }\end{array}$} & & CT & \multirow[b]{2}{*}{5} & \multirow{2}{*}{$\begin{array}{l}\text { emerging } \\
\text { emerging }\end{array}$} \\
\hline & & CT, ST & & \\
\hline $\begin{array}{l}\text { 6. Knowledge and } \\
\text { Skills }\end{array}$ & $\begin{array}{l}\text { Demonstration of } \\
\text { candidate's development of } \\
\text { skills and knowledge }\end{array}$ & $\mathrm{F}, \mathrm{CT}, \mathrm{ST}$ & 53 & a priori \\
\hline $\begin{array}{l}\text { a. Classroom and } \\
\text { school routines }\end{array}$ & & CT, ST & 13 & emerging \\
\hline $\begin{array}{l}\text { b. Classroom } \\
\text { management }\end{array}$ & & CT, ST & 4 & emerging \\
\hline c. Differentiation & & ST & 8 & emerging \\
\hline $\begin{array}{l}\text { d. District } \\
\text { expectations }\end{array}$ & & $\mathrm{F}, \mathrm{CT}$ & 7 & emerging \\
\hline $\begin{array}{l}\text { e. Lesson } \\
\text { planning } \\
\text { and enacting }\end{array}$ & & CT, ST & 8 & emerging \\
\hline $\begin{array}{l}\text { f. Developing } \\
\text { teacher identity }\end{array}$ & & ST & 6 & emerging \\
\hline 7. Praxis & $\begin{array}{l}\text { Theoretical understanding } \\
\text { to practical application } \\
\text { through action and } \\
\text { reflection }\end{array}$ & F, CT, ST & 52 & emerging \\
\hline $\begin{array}{l}\text { a. Theory to } \\
\text { practice }\end{array}$ & & $\mathrm{F}, \mathrm{CT}, \mathrm{ST}$ & 12 & emerging \\
\hline $\begin{array}{l}\text { b. Realistic } \\
\text { expectations }\end{array}$ & & F, CT, ST & 13 & emerging \\
\hline $\begin{array}{l}\text { c. Reflective } \\
\text { practice }\end{array}$ & & F, CT, ST & 22 & emerging \\
\hline $\begin{array}{l}\text { Note. } \\
\text { addapted from CA } \\
\text { Educator Preparati } \\
\text { b Sources reflect foc } \\
\text { ST (Student Teache }\end{array}$ & $\begin{array}{l}\text { P Accreditation Standards } \\
\text { (CAEP, 2013). } \\
\text { s groups. F (University Fact }\end{array}$ & nd Evide & & $\begin{array}{l}\text { ins for } \\
\text { acher), }\end{array}$ \\
\hline
\end{tabular}

\section{Depth, Breadth, and Duration}

According to the CAEP Standard 2.3, the provider and partners design practitioner experiences of "sufficient depth, breadth ... and duration to ensure that candidates demonstrate effectiveness and positive impact on student learning" (CAEP, 2013). Researchers identified 11 references to depth, breadth, and duration 
that addressed the general structure of CSU's EPP and acknowledged the phases of instruction provided depth and breadth through the requirements of practitioner experiences in elementary, middle, and high schools and duration through the expectation of 800 hours of practitioner practice. Nonetheless, while CSU embeds practitioner experiences in four semesters of coursework, comments from both SBTEs and teacher candidates expressed a desire for more practitioner experiences. One SBTE explained:

I wish there was more of it in the classroom, because as teachers, you learn when you're in the classroom in front of kids. Just getting the theoretical stuff is nice, but it's not enough. Once you implement it, you learn a lot more. So, from my experience, I wish I was in the classroom more, teaching more lessons, just learning on the spot.

Echoing those sentiments, a teacher candidate stated:

That's the only thing that I would change . . . is that in that first semester when you first go to that first middle school or elementary school, I would have them teach-within that first semester a couple times, like fully in front of the whole class-teach a full lesson. Even two, three, four times and then watch because I feel like I didn't really know what I was looking for those first two semesters until I actually taught and then I was like, "That's why they're standing near that kid; it's because they're trying to get him to be quiet."

\section{Knowledge and Skills}

According to the CAEP Standard 2.3, experiences have multiple assessments to demonstrate candidates' development of knowledge, skills, and professional dispositions associated with a positive impact on learning and development of P-12 students. The requisite knowledge and skills are clarified in CAEP Standard 1.1 which has stated, "Candidates demonstrate an understanding of the 10 [Interstate Teacher Assessment and Support Consortium] InTASC standards at the appropriate progression level(s) in the following categories: the learner and learning; content; instructional practice; and professional responsibility" (CAEP, 2015). Included in the InTASC standards, the Council of Chief State School Officers (CCSSO) (2011) outlined knowledge and skills such as, "the teacher uses understanding of individual differences and diverse cultures and communities to ensure inclusive learning environments that enable each learner to meet high standards" (p. 11); "the teacher has a deep knowledge of student content standards and learning professions in the discipline s/he teaches" (p. 13); 
and, "the teacher individually and collaboratively selects and creates learning experiences that are appropriate for curriculum goals and content standards, and are relevant to learners" (p. 16).

The researchers identified 53 references to the theme, knowledge and skills, as well as six emerging subthemes. No subtheme was referenced by all three stakeholder groups. Teacher candidate transcripts included references to classroom and school routines, classroom management, lesson planning and enacting, differentiation, and developing teacher identity. SBTEs also referenced classroom and school routines, classroom management, and lesson planning and enacting as well as district expectations. UBTEs' transcripts only referenced district expectations.

Concrete skills and soft skills. Comments by both teacher candidates and SBTEs about the acquisition of concrete skills, such as lesson planning and presentation, classroom management and daily routines, like taking role and handing back papers confirmed that the practitioner experiences provided the opportunity for teacher candidates to master basic tasks associated with being a teacher.

Additionally, the teacher candidate transcriptions reflected an increased knowledge concerning the complexities of teaching and the acquisition of the less measurable soft skills, such as working in teams, understanding resources to support student learning, appreciating the scope of daily teacher responsibilities and refining their teacher identity. Talking about the scope of teacher responsibilities, one teacher candidate said:

I never saw it in my other levels. It took student teaching to really, really realize how much housekeeping needs to be done.... All those different things that I learned through student teaching, I think that really just opened my eyes to all the aspects of being a teacher.

In discussing the importance of knowing with whom and how to collaborate, another teacher candidate expressed:

The importance of collaboration between case managers, counselors and teachers ... If you're not talking to that case manager... if you're not talking to your counselor...then you're going to have problems . . .because they can address things outside of your classroom that will benefit both the student and the rest of your class.... I wouldn't have expected to be talking to as many coaches as I do but I'm constantly emailing coaches. 
Differentiating Instruction. The teacher candidates' practitioner experience also gave them insight into the importance of differentiating instruction as well as the opportunity to practice it. One teacher candidate commented, "The diversity from your lowest performing student to your highest ...you're just forced to differentiate."

Teacher candidate quotes expressed the development of a deeper knowledge of their teacher identity because of the varied practitioner experiences afforded them. Even if they did not agree with the approach of a mentor teacher, the student teachers saw the value of the multiple and diverse experiences. One student said, "It's nice to see what I like and what I don't like. I mean, I now know who I want to be as an educator." Another student stated that the practitioner experience was "a great opportunity to learn how other people did all these things and to see how I wanted to do it for myself." Finally, another student said, "I'm finding my teacher voice among all of those different influences."

The UBTEs' comments reflected the idea that the knowledge and skills gained by the teacher candidates during their practitioner experiences made them more desirable to hire and described the teacher candidates' practitioner experience as "a year-long interview basically." Another university faculty member who was previously an administrator in one of the local partnership schools expressed preference for hiring teacher candidates from CSU because their practitioner experience through the PDS program prepared them better than candidates from other programs:

When I was an administrator in the district, I always put the CSU students at the top because they were the best candidates typically, because they weren't coming to us as first year teachers. They were coming at us with second and third year experiences and dispositions.

\section{Professional Dispositions}

As defined by CAEP professional dispositions are the "habits of professional action and moral commitments that underlie an educator's performance" ("Dispositions," 2015). Professional dispositions reflect values such as caring, fairness, responsibility, a vision of high standards for all students, and social justice (National Council for Accreditation of Teacher Education [NCATE], 2010). Along with content and pedagogical knowledge, the development of professional dispositions that foster learning in students is an essential component of an effective educator preparation program (Taylor \& Wasicsko, 2000). 
Mandated by the CAEP Standard 2.3, "[practitioner] experiences [must] have multiple assessments to demonstrate candidates' development of knowledge, skills and professional dispositions associated with a positive impact on learning and development of P-12 students" (CAEP, 2015). The requisite professional dispositions are clarified in CAEP Standard 1.1 which states:

Candidates demonstrate an understanding of the 10 Interstate Teacher Assessment and Support Consortium (InTASC) standards at the appropriate progression level(s) in the following categories: the learner and learning; content; instructional practice; and professional responsibility. (CAEP, 2013)

Embedded in the InTASC standards are professional dispositions, such as "the teacher believes that all learners can achieve at high levels and persists in helping each learner reach his/her full potential" (p. 11); "the teacher respects learners" diverse strengths and needs and is committed to using this information to plan effective instruction" (p. 16); and, "the teacher takes initiative to grow and develop with colleagues through interactions that enhance practice and support student learning" (CCSSO, 2011, p. 19).

The researcher identified 23 references addressing professional dispositions from the three stakeholder groups. Again, no subtheme was referenced by all three stakeholders. Teacher candidate transcriptions included references to collaboration, value of feedback, learning from mistakes, and care and compassion. SBTEs also referenced learning from mistakes, as well as and. UBTEs also referenced collaboration.

Collaboration. When discussing collaboration, both the UBTEs and the SBTEs highlighted the concept of simultaneous renewal (Goodlad, 1994) and that the collaboration benefited everyone: PK-12 students, the teacher candidates, SBTEs and UBTEs. One SBTE said, "We worked together...we teamed up together, and that was a really good experience for me .... It was beneficial for us and for the kids." In a reference to collaboration, a UBTE said:

If you really believe in simultaneous renewal, it doesn't have to be the best teacher in that department because you look at their willingness to grow and to learn and the benefit to them, and look at the skills of the student.... Then you can create really great partnerships.... Our mission is to improve everyone. 
Value of feedback. Regarding the value of feedback, SBTEs discussed that the practitioner experiences provided a "safe space ... to get safe feedback" for the teacher candidates, but identified inadequate time in the schedule as a barrier to providing valuable feedback especially to teacher candidates who are on-site only two times per week. SBTEs discussed the importance for teacher candidates to develop the disposition of being open-minded to feedback. One SBTE explained an approach to feedback, which was to ask the teacher candidate for feedback on instruction: "Turn that back on them to give us feedback, because then I think it opens them up more to our feedback. It's a very give and take relationship."

Learning from mistakes. Both SBTEs and teacher candidates talked about the value of practitioner experiences as a safe environment to practice, make mistakes, and learn from mistakes. As a new teacher, developing the disposition to learn from mistakes is important because teachers should, themselves, be lifelong learners. Being able to learn from mistakes and model that disposition for students teaches students to be resilient and see failure as an opportunity for growth. One SBTE said of the practitioner experiences, "I feel like it's a safe space for the PDS students to make mistakes ... so it's okay to make a mistake. I think that's a really important piece on how we grow." Teacher candidates addressed the idea that the practitioner experiences were designed as a safe space for teacher candidates to try out a new instructional strategy or incorporate a new activity. One teacher candidate remarked, "I think that was emphasized throughout the program: You're going to make mistakes. Just learn from them. They're not the end of the world." Another student teacher said, "It's hard to admit when you're wrong, but it's valuable."

Care and compassion. Teacher candidates spoke of the responsibility they felt as educators to treat students with respect, fairness, and kindness as well as their own frustration that often there was not enough time in the day to meet the needs of all students. One teacher candidate said:

I just have so much to do and I have about half the time to actually do all the things I needed to do, and that is somewhat frustrating. There are times where it's like I wish I had an extra five minutes in that period to really talk to one kid that's having a rough time.

In reply, another student teacher said:

I'll take five minutes at the end of the day, write [the struggling student] a letter or something, but that's five more minutes somewhere else that I had to move. So, it's just a time issue-just not enough minutes in the day. 
Finally, in response, one student teacher said, "The only thing that is inexcusable is lack of effort or caring when it comes to students." Based on the comments of the teacher candidates, it was evident that the practitioner experiences provided them the opportunity to develop the professional disposition of care and compassion regarding their students.

\section{Praxis}

Praxis was not specifically mentioned in the CAEP Standard 2.3 and was added as an emerging theme as the researcher coded the data. In this analysis, the term praxis is used to describe the process by which theory is enacted or realized through action in combination with reflective practice. It is action based on reflection and embodies qualities that include a commitment to human well-being, respect for others and a search for truth (Carr \& Kemmis, 1986). Also important is the iterative nature of praxis. Theory influences practice; practice informs theory. Teaching experiences shape theoretical frameworks about teaching. Quinlan (2012) explained that "praxis could be summed up as "informed action"” (para. 5). Praxis "is the process of taking action in practice whilst acting within a theoretical framework of thought. In this concept, theory and practice are as one" (Quinlan, 2012, para. 5). Described as such, the concept of praxis was referenced by all three stakeholder groups, a total of 52 times. Three specific subthemes emerged as the focus groups described their practitioner experiences: theory to practice, realistic expectations, and reflective practices.

Theory to practice. Both SBTEs and UBTEs described the embedded practitioner experiences as the space where student teachers learn how to enact pedagogical and content theory. It is in this space that the complexities of teaching, reflecting, analyzing, revising and again teaching begin to coalesce for teacher candidates. One SBTE said:

When you're learning about pretty complex theories and how kids are learning things, and then being able to implement it in the classroom, it's really a big job because most of the decisions we make aren't necessarily based on educational theories, they're based on personal interactions with kids.

\section{A UBTE stated:}

I also think that's where the complexities of teaching really start to emerge for our students, because I think when they're sitting in course work and then in theory, it seems pretty common sense, really not too complex, but 
it's when that step goes [to] the application level that they start to realize what the complexities of teaching are.

Teacher candidates also discussed the greater understanding of the complexities of teaching that emerged as they transitioned from university classroom theory to practical application. Of their practitioner experiences one teacher candidate said, "You know, just the little things that you can't get from [sitting in] a classroom and you just have to be in front of them, in front of the class." Another student teacher added, "You just can't really think about it until you're fully in that role as a teacher."

Realistic expectations. Practitioner experiences were identified as a way to create realistic expectations about teaching for the teacher candidates. UBTEs, SBTEs, and teacher candidates talked about how theories and beliefs about teaching changed through the process of praxis and became more grounded in application as the teacher candidates enacted their theories in the classroom. At times this process was seen as positive and other times difficult, but in all cases, the process of developing realistic expectations was seen as an important part of being prepared as a new teacher.

A teacher candidate talked about her initial idealism as she entered her student teaching experience:

Coming in I was like, 'I'm going to fix everyone.' .... You only have so much time in the day. First of all, you've got to get them to come to your class, and then once they're there ... you can give them all the sage wisdom you have..... You can't make them write.... You can't.

A UBTE discussed a shift in thinking from idealistic to more realistic through the process of praxis:

Students come in with a very idealistic thought about who good teachers are, what their classrooms look like, how they plan, how they work with each other, how kids are going to react, what lesson planning looks like. And then they really get immersed in it, and realize that it's maybe not exactly what their idealistic view was, and so having our students out and experiencing that with people who can support them through that experience is huge.

Reflective practice. Reflective practice is an essential component of praxis and was referenced by UBTEs, SBTEs, and teacher candidates. Overall, comments 
addressed the fact that the practice of reflection was well integrated into the teacher preparation program throughout all phases of the practitioner experience. All stakeholders appreciated the value of reflection as an opportunity for participants to become better teachers. One SBTE stated, "From a PDS student standpoint, I think that [reflective practice] is probably one of the most important things." A UBTE spoke about the value of reflective practice:

[The teacher candidates] have this experience, but they need to talk about it, process it, share those experiences with each other .... The seminar and that chance to dialogue is really what makes a difference because that becomes the reflective part of teaching.

A teacher candidate spoke about an initial reluctance to embrace the reflective practices but a realization of its value, stating:

At every stage, we've just been forced to reflect upon our experiences. My first education class, I walked in and was like, 'Not going to be doing well with this touchy-feely crap,' and by the end of it, I don't think it just made me a better teacher, it made me a better person.

\section{Discussion}

\section{Description of the CSU PDS Practitioner Experiences}

The first question this study endeavored to answer was to describe the practitioner experiences embedded in CSU's PDS model of educator preparation as understood by CSU CEP faculty, SBTEs, and teacher candidates participating in the focus groups. The findings showed a high level of consistency among the focus groups with regard to their description of the practitioner experiences. Each group acknowledged that the varied and multi-year practitioner experiences in CSU's PDS model provided many opportunities for student teachers to learn and grow. Although different subthemes were highlighted depending on the role of the participants in the partnership, each of the groups discussed the acquisition of knowledge, skills, and professional dispositions that combined to create quality teacher candidates. These skills and dispositions reflected the existing body of research that points to the benefits of teacher preparation programs with extensive embedded practitioner experiences versus the more traditional preparation programs (Sandholtz \& Wasserman, 2001). The SBTEs spoke specifically about teacher candidates being better prepared than a typical first year teacher prepared elsewhere, in part because of the increased exposure to school district expectations. Similarly, studies comparing PDS and traditional teacher preparation programs 
have found that graduates from PDS programs were better prepared for the realities of day to day teaching and entered the profession at more advanced levels of beginning teacher development and more like second-year teachers (Castle et al., 2006; Dadlez \& Sandholtz, 2001; Sandholtz \& Dadlez, 2000; Walling \& Lewis, 2000). The SBTEs' and teacher candidates' descriptions of the benefits of practitioner experiences were supported in prior research, particularly comparison studies between PDS and traditional teacher preparation (Castle et al. 2006; 2009). Positive differences between PDS and traditionally prepared teacher candidates were identified, two of which were reflected in the findings of this study: A more integrated experience and more connections between theory, reflection, and practice.

All focus groups shared the perception that practitioner experiences provided the space for teacher candidates, guided by UBTEs and SBTEs, to connect theory to practice and engage in reflective practice, which was another benefit cited in the literature as a key element to quality teacher preparation programs. Castle et al., 2006 supported CSU faculty's understanding of the value of praxis as an integral component of the practitioner experience that enabled PDS student teachers to "make more connections between theory and practice, integrate those connections into their thinking and practice . . . and negotiate the give-and-take between the ideal and the implementation" (p. 65). SBTEs discussed the value of practitioner experiences to engage teacher candidates in reflective practice. Developing teacher candidates' capacity to participate in and learn from critical reflection, one component of praxis, has been identified as an effective facet of practitioner experiences (Bennett, 2013) and as an effective practice in developing higher levels of professional maturity (Wait \& Warren, 2002).

\section{Alignment of the CSU PDS Practitioner Experiences with CAEP Standard 2}

The second question this study endeavored to answer was how the descriptions of CSU's practitioner experiences by CSU CEP Faculty, SBTEs and teacher candidates aligned with the Practitioner Experiences defined by CAEP Standard 2.3. Using the essential elements from the language of the CAEP Standard 2.3 to develop the a priori codes for the analysis of the data, these codes provided a framework to compare the responses of the three focus groups to the CAEP standard. The researcher looked at two factors to determine alignment: The total number of references made to a particular code and the source (UBTE, SBTE, teacher candidate) of the reference. If the code was not cited by all three references and had fewer than ten references, the researcher did not consider there to be enough evidence to indicate alignment with the standard. For the code assessment, there were two references made by two sources. For the code diversity, three 
references were made by two sources. The code impact on P-12 students was referenced three times from two sources. The researchers determined that for these codes, there was insufficient evidence to claim alignment with the standard. The researchers has considered the reason for the lack of references to these particular codes in the focus group data. One possible explanation is that the formulation of the interview guiding questions, asking participants to explain the benefits of and barriers to practitioner experiences did not elicit responses that led to comments about the codes assessment, diversity, and impact on P-12 students.

Three codes, depth, breadth and duration, knowledge and skills, and professional dispositions, were referenced more than 10 times by all three sources, thus providing enough evidence for the researchers to consider alignment with the standard. At 11 references, the evidence for depth, breadth and duration was adequate but certainly not overwhelming. This may be due in part to the longevity of the CSU PDS partnership that has been in place for nearly two decades. The well-established, multiple-semester practitioner experiences may be taken for granted by long term participants. Additionally, many of the SBTEs participating in the focus groups are graduates of CSU's PDS program and have no other frame of reference. With 23 references for professional dispositions and 53 references for knowledge and skills, the researcher found overwhelming evidence that participants' description of the practitioner experiences leading to teacher candidates' development of professional dispositions and knowledge and skills to become effective educators met the expectations set forth in CAEP Standard for Practitioner Experiences (CAEP, 2013).

Although diversity and impact on student learning was not an emergent theme based on responses to the questions asked, researchers agreed that there was a consistent thread throughout all the responses that the partnership must specifically benefit the PK-12 students as the foundation for all other activities.

\section{Conclusion}

This paper reported the findings of a qualitative study which sought to describe the practitioner experiences embedded in CSU's educator preparation program as understood by the key stakeholders, CSU CEP faculty, local schoolbased educators and teacher candidates, through the lens of the CAEP accreditation standards for Practitioner Partnerships and Practice (CAEP, 2013). The findings showed that all three stakeholder groups described the practitioner experiences as crucial to the teacher candidates' development of knowledge and skills and professional dispositions to become effective educators. The practitioner experiences were also described as the space where theory and practice intersect 
with reflective practice to provide the teacher candidates opportunities to experience and navigate the complexities involved in teaching. The researchers concluded that sufficient evidence existed in the data to assert that three themes of the CAEP Standard 2.3 (depth, breadth and duration, professional dispositions, and knowledge and skills) were reflected in the stakeholders' descriptions of the practitioner experiences of CSU PDS. This is important feedback because of CSU's commitment to maintain national accreditation through CAEP. Finally, these findings add to the body of literature supporting the continued development and implementation of practitioner partnerships as an effective strategy to renew and improve the quality of educator preparation programs, which in turn, prepare quality teachers to educate children.

Teaching requires a highly complex skill-sets and a refined knowledge base that is created over-time through rigorous practice-based experiences in schools. There are many promising, and yet disparate, approaches around the country with great range in knowledge and skills to candidate preparation. For years, EPPs have struggled with defining the specific skills and knowledge teacher candidates need to know and be able to do. Because of new CAEP standards that blend theory with practice in clinical school-based settings, EPPs are in a position to describe the skills, high-leverage practices, and educator knowledge that all teacher candidates must demonstrate.

To place clinical experiences at the core of educator preparation requires a paradigm shift, making the experiences primary and the theory embedded in and serving to support those experiences. This shift of thinking and program restructure will take commitment, communication, engagement, and resources on the part of all stakeholders involved in a university/school district clinical partnership, but holds tremendous potential to better prepare future educators. 


\section{References}

Abdal-Haqq, I. (1998). Professional development schools: Weighing the evidence. Thousand Oaks, CA: Corwin Press.

American Association of Colleges for Teacher Education [AACTE]. (2010, June). Reforming teacher education: The critical practitioner component. In R. S. Rochon (Chair) \& S. P. Robinson (President), AACTE Day on the Hill. Symposium conducted at the meeting of AACTE, Washington, DC.

Bennett, S. (2013). Effective facets of a field experience that contributed to eight preservice teachers' developing understandings about culturally responsive teaching. Urban Education, 48(3), 380-419. doi:10.1177/0042085912452155

Boyd, D., Grossman, P., Lankford, H., Loeb, S., \& Wyckoff, J. (2009). Teacher preparation and student achievement. Educational Evaluation and Policy Analysis, 31(4), 416-440. doi:10.3102/0162373709353129

Carnegie Forum on Education and the Economy, Task force on Teaching as a Profession. (1986).

A nation prepared: Teacher for the $21^{\text {st }}$ century: The report of the Task Force on Teaching as a profession. New York, NY: Carnegie Forum on Education and the Economy.

Carr, W., \& Kemmis, S. (1986) Becoming critical: Education, knowledge and action research. Lewes, DE: Falmer Press.

Castle, S., Arends, R., \& Rockwood, K. (2008). Student learning in a professional development school and a control school. The Professional Educator, 32(1), 1-16. Retrieved from http://search.proquest.com

Castle, S., Fox, R., \& Fuhrman, C. (2009). Does professional development school preparation make a difference? A comparison of three teacher candidate studies. School-University Partnerships, 3(2), 58-68. Retrieved from https://eric.ed.gov 
Castle, S., Fox, R., \& Souder, K. (2006). Do professional development schools (PDSs) make a difference? Journal of Teacher Education, 57(1), 65-80. doi:10.1177/0022487105284211

Cochran-Smith, M. (2006). Policy, practice, and politics in teacher education. Thousand Oaks, CA: Corwin Press.

Council for the Accreditation of Educator Preparation [CAEP], CAEP Commission on Standards and Performance Reporting to the CAEP Board of Directors. (2013). CAEP accreditation standards and evidence: Aspirations for educator preparation [report]. Retrieved from http://docplayer.net/11050566-Caep-accreditation-standards-andevidence-aspirations-for-educator-preparation.html

Council for the Accreditation of Educator Preparation [CAEP]. (2015). Standard 2: Practitioner partnerships and practice. Retrieved from http://caepnet.org/standards/standard-2

Council of Chief State School Officers [CCSSO]. (2011). InTASC model core teaching standards: A resource for state dialogue [pdf]. Retrieved from http://www.ccsso.org/Documents/2011/InTASC_Model_Core_Teaching_ Standards_2011.pdf

Dadlez, S. H., \& Sandholtz, J. H. (2001). The link between teacher education and beginning teachers' development. In J. Rainer \& E. M. Guyton (Eds.), Research on the effects of teacher education on teacher performance: Teacher education yearbook IX (pp. 153-168). Dubuque, IA: Kendall/Hunt.

Darling-Hammond, L. (2006). Constructing $21^{\text {st }}$-century teacher education. Journal of Teacher Education, 57(3), 300-314. doi:10.1177/0022487105285962

Dispositions. (2015). In Council for the Accreditation of Education Programs Glossary. Retrieved from http://caepnet.org/glossary?letter=D

Elo, S., \& Kyngäs, H. (2008). The qualitative content analysis process. Journal of Advanced Nursing, 62(1), 107-115. doi:10.1111/j.13652648.2007.04569.x 
Goodlad, J. (1994). Educational renewal: Better teachers, better schools. San Francisco, CA: Jossey-Bass.

Goodlad, J. (1990). Teachers for our nation's schools. San Francisco, CA: JosseyBass.

Levine, M. (1992). Professional practice schools: Linking teacher education and school reform. New York, NY: Teacher College Press.

Merriam, S. B. (1998). Qualitative research and case study applications in education (2nd ed.). San Francisco, CA: Jossey-Bass.

Miles, M. B., \& Huberman, A. M. (1994). Qualitative data analysis: An expanded sourcebook (2nd ed.). Thousand Oaks, CA: Sage.

Model of the teacher licensure program for the secondary and K-12 programs [PDF]. (2012). Retrieved from http://www.cep.chhs.colostate.edu/students/teacher/files/ModeloftheTeach erLicensureProgram-December2012.pdf

Morgan, D. L. (1997). Focus groups as qualitative research (2nd ed.). Newbury Park, CA: Sage.

Murray, F. (1986). Goals for the reform of teacher education: An executive summary of the Holmes Group report. Phi Delta Kappan, 68(1), 28-32. Retrieved from http://www.jstor.org

National Council for Accreditation of Teacher Education [NCATE]. (2010). Transforming teacher education through practitioner practice: A national strategy to prepare effective teacher. Retrieved from www.ncate.org/publications

National Commission on Excellence in Education, A report to the Nation and the Secretary of Education, United States Department of Education. (1983). A nation at risk: The imperative for educational reform [pdf]. Retrieved from http://www.maa.org/sites/default/files/pdf/CUPM/first_40years/1983Risk.pdf 
National Research Council. (2010). Preparing teachers: Building evidence for sound policy [report]. Retrieved from http://www.nap.edu/catalog.php?record_id=12882

Onwuegbuzie, A. J., Dickinson, W. B., Leech, N. L., \& Zoran, A. G. (2009). A qualitative framework for collecting and analyzing data in focus group research. International Journal of Qualitative Methods, 8(3), 1-21. doi:10.1177/160940690900800301

Professional development schools. (2015). In Council for the Accreditation of Education Programs Glossary. Retrieved from http://www.caepnet.org/glossary?letter=P

Professional development schools and partnerships. (2015). Retrieved from http://www.stepp.chhs.colostate.edu/students/partners/index.aspx

Quinlan, O. (2012). Praxis: bringing theory and practice to teaching [blog post]. Retrieved from_http://www.oliverquinlan.com/blog/2012/10/23/praxisbringing-theory-and-practice-to-teaching/

Sandholtz, J., \& Dadlez, S. (2000). Professional development school trade-offs in teacher preparation and renewal. Teacher Education Quarterly, 27(1), 728. Retrieved from http://www.jstor.org

Sandholtz, J., \& Wasserman, K. (2001). Student and cooperating teachers: Contrasting experiences in teacher preparation programs. Action in Teacher Education, 23(3), 54-65. doi:10.1080/01626620.2001.10463075

Smith, L. M. (1978). An evolving logic of participant observation, educational ethnography and other case studies. In L. Shuman (Ed.), Review of research in education (pp. 316-377). Itasca, IL: Peacock.

Stake, R.E. (2000). Case studies. In N. Denzin \& Y. Lincoln (Eds.), Handbook of qualitative research (pp. 435-454). Thousand Oaks, CA: Sage.

Taylor, R. L., \& Wasicsko, M. M. (2000). The dispositions to teach. In annual meeting of the South Regional Association of Teacher Education, Lexington, KY.

Wait, D., \& Warren, L. (2002). Reforming teacher education through professional development schools. International Journal of Educational Reform, 11(3), 
228-249. Retrieved from https://eric.ed.gov

Walling, B., \& Lewis, M. (2000). Development of professional identity among professional development school preservice teachers: Longitudinal and comparative analysis. Action in Teacher Education, 22(2), 65-72. doi:10.1080/01626620.2000.10463040

Williams, C. T. (2000). Teaching as a Profession: A national education association perspective [pdf]. Retrieved from http://images.pearsonassessments.com/images/NES_Publications/2002_07 Williams_474_1.pdf

Zimpher, N. L., \& Howey, K. R. (2013). Creating 21st-century centers of pedagogy: Explicating key laboratory and practitioner elements of teacher preparation. Education, 133(4), 409-421. Retrieved from http://search.proquest.com 